\title{
EVALUATION OF TOXICITY AND RESPONSE OF AFRICAN CATFISH (Clarias gariepinus) EXPOSED TO MANGANESE CHLORIDE SOLUTION
}

\author{
Awolola, T. M. ${ }^{1}$ *Areola, J. O. ${ }^{2}$, Aladesanmi, T. T. ${ }^{1}$, Arayombo, B. E. ${ }^{3}$ \\ Institute of Ecology, Obafemi Awolowo University, Ile-Ife. \\ ${ }^{2}$ Department of Medical Biochemistry, Obafemi Awolowo University, Ile -Ife. \\ ${ }^{3}$ Department of Anatomy and Cell Biology, Obafemi Awolowo University, Ile -Ife \\ *Corresponding author's e-mail address: dayoareola@yahoo.com. \\ E-mail addresses of other authors: ATM- martolux@gmail.com;_ATT-ttaladesanmi@yahoo.com; ABE- \\ arayombo82@gmail.com
}

(Received: $12^{\text {th }}$ November, 2019; Accepted: $11^{\text {th }}$ March, 2020)

\section{ABSTRACT}

\begin{abstract}
This study investigated the acute toxicity and behavioural response of African catfish (Clarias gariepinus) to manganese chloride $\left(\mathrm{MnCl}_{2}\right)$ solution. One hundred (100) pieces of juvenile Clarias gariepinus were acclimatized for 14 days in ten (10) plastic bowls containing $25 \mathrm{~L}$ of water each. The acute-toxicity of manganese chloride, $\mathrm{LC}_{50}$ and sub chronic exposure (28 days) were investigated. For sub-lethal exposure; fifty pieces of C. gariepinus were divided into five groups of ten in bowls labelled (A to E). The fish in groups (A to D) were exposed to manganese chloride solutions at: $68.5,137,205.5$ and $274 \mathrm{mg} / \mathrm{L}$ respectively while group G served as the control. On day 28, the exposed fish were sacrificed; blood, muscle, liver, and gills were collected for haematological and histological studies. The activities of the superoxide dismutase (SOD) and glutathione-Stransferase (GST) were determined using standard methods. The manganese concentrations in the liver, gills and muscle tissues were determined using Atomic Absorption Spectrophotometer (AAS). The $\mathrm{LC}_{50}$ obtained was $2.74 \mathrm{~g} / \mathrm{L}$. The mean water temperature showed that there was no significant variation at $(\mathrm{p}<0.05)$ between the control and other groups. The results of growth parameters showed that fish exposed to $137 \mathrm{mg} / \mathrm{L}$ manganese concentration had better growth performance than those exposed to higher concentrations. The activities of SOD and GST in the liver of fish increased significantly $(\mathrm{p}<0.05)$ as manganese concentration increases. The red blood cells concentrations decreases while white blood cells increases as the concentration of manganese increases respectively. The mean bioaccumulation of manganese in the organs of C. gariepinus followed the order of liver $>$ gill $>$ muscle. The histopathological study revealed alterations in the liver, gill and muscle tissues. This study concluded that manganese at concentration greater than $137 \mathrm{mg} / \mathrm{L}$ elicits adverse effect on C. gariepinus growth performance, haematology, histopathology as well as liver SOD and GST activities.
\end{abstract}

Key words: Behavioural response, Cat-fish, Juvenile, Manganese chloride, Toxicity

\section{INTRODUCTION}

Rivers and ponds are polluted due to the indiscriminate discharge of domestic, agricultural and industrial effluents which are toxic and contribute to the deterioration of water quality by changing its physicochemical nature leading to stress on aquatic organisms (Kamble and Tapale, 2011, Adesina et al., 2018). Manganese (Mn) is the twelfth most abundant element which makes up about $0.1 \%$ of the Earth's crust. It exists in a variety of oxidation states, $\mathrm{Mn}^{2+}$ and $\mathrm{Mn}^{3+}$ being the most biologically important.

Although the elemental (metal) form of manganese does not occur naturally in the environment, manganese is a component of over 100 minerals. Metal contamination of aquatic ecosystems has long been recognized as a serious pollution problem (Baby et al., 2010). The African catfish inhabits a wide range of water bodies including swamps, lakes and rivers; they thrive in harsh environmental conditions including muddy, turbid and oxygen depleted water bodies with the aid of their accessory air breathing organ (labyrinth organ) that allows them to breathe atmospheric oxygen. It has been observed that catfish from dirty ponds bioaccumulate metals, thus posing a great threat to the health of consumers (Farombi et al. 2007).

Manganese is an essential nutrient in animals; it plays a role in bone mineralization, protein and energy metabolism, metabolic regulation, cellular protection from damaging effect of free radical species and formation of glycosaminoglycans. In the last century, the massive production of 
manganese-containing compounds (chemical products, alloys, steel, iron, ceramics and fungicide products) has attracted the attention of scientists who investigated manganese as a potential emerging contaminant in the environment, and especially in the marine environment (CICAD, 2004). In humans, excessive exposure to manganese has been shown to cause neurotoxicity, associated with a characteristic syndrome called 'manganese madness' or 'Parkinson-like' diseases (Perl and Olanow, 2007).

In humans, the neurological damage induced by excessive manganese exposure has been well documented for over a century (Takeda, 2003). Manganese toxicity in human could lead to serious neurological and reproductive disorders. The anthropogenic source of contamination is usually through industrial activities. It has been observed that C. gariepinus is one of the most cultured and consumed fish species in Nigeria and it bioaccumulates metals (including manganese) when cultured in polluted ponds. This study was designed to evaluate the toxicity of African catfish C. gariepinus exposed to manganese chloride solution.

\section{MATERIALS AND METHODS \\ Fish Collection and Acclimatization}

One hundred (100) 8-10 weeks old C. gariepinus; $30-45 \mathrm{~g}$ belonging to a single population were purchased from the hatchery unit, Department of Fisheries and Aquaculture, Obafemi Awolowo University, Ile-Ife, Nigeria. The test organisms were kept in a large plastic container and acclimatized for a period of fourteen days. During acclimatization, renewal bioassay was employed and fish were fed twice daily with fish feed (Copens) of about $40 \%$ crude protein content. The water used was obtained from hand dug well in the Faculty of Agriculture, Obafemi Awolowo University., Campus, Ile-Ife.

\section{Reagents and Chemicals}

The reagents used were of analytical grade. They were obtained from various sources such as Sigma Fine Chemicals Limited, Sweden, British Drug House Limited, London and Oxford Laboratory Reagents, Mumbai, India

\section{TOXICOLOGICAL INVESTIGATION Toxicity Range Finding Test}

The range finding test was carried out to determine the definitive concentrations of manganese to be used for the toxicity evaluation according to the procedure described by ASTM (2007). Four (4) test solutions were prepared in stock bowls labelled A-D containing varying concentrations of manganese chloride and a control. Ten (10) fish were kept in each bowl and observed for mortality after $24,48,72$, and $96 \mathrm{hr}$ as described by Reish and Oshida, (1987). Toxicity range of manganese concentration to $C$. gariepinus was then estimated from the mortality results.

\section{Acute Toxicity Study and $\mathrm{LC}_{50}$ Determination}

The results obtained from the toxicity range finding test was used as a guide for the acute toxicity test. Four (4) different concentrations of manganese chloride were prepared in four plastic bowls $(2.0,3.0,4.0$ and $5.0 \mathrm{~g} / \mathrm{L})$ and control, this set was used for the $96 \mathrm{hr}$ acute toxicity studies in a static exposure system (Obuotor, 2004). Five (5) Clarias gariepinus juveniles $(50 \pm 4 \mathrm{~g})$ were introduced carefully into each of the bowls containing the test solutions in duplicate. The behavioural response of fish to varying concentrations of manganese chloride was observed as well as mortality in each of the exposure chambers and these were recorded after $12,24,48,72$, and $96 \mathrm{hr}$. The $96 \mathrm{hr} \mathrm{LC}_{50}$ value was then calculated from the data obtained using probit method (Finney, 1971).

\section{Sub chronic Toxicity Study}

Fifty (50) C. gariepinus were divided into five groups (A to E) in duplicates and the experimental fish was exposed to test solutions containing the following manganese concentrations: $68.5,137$, 205.5 and $274 \mathrm{mg} / \mathrm{L}$ which represent 2.5, 5.0, 7.5 and $10 \%$ of $\mathrm{LC}_{50}$ respectively), group $\mathrm{E}$ is the control. Static/renewal bioassay was employed in the experiment and the test solutions were renewed every $48 \mathrm{hr}$ with freshly prepared solutions in order to maintain stable concentration of the metal and to minimize waste accumulation.

Physicochemical parameters of the water used were determined and recorded; they are dissolved 
oxygen, $\mathrm{pH}$, temperature and conductivity. Careful observations were made to determine the growth response and toxicity of the solution to $C$. gariepinus. The fish were fed at the rate of $5 \%$ of their body weight between the hours of $7.00 \mathrm{hr}$ $8.00 \mathrm{hr}$ and $18.00 \mathrm{hr}-19.00 \mathrm{hr}$ during the exposure period that lasted for four weeks ( 28 days). The feed was withdrawn $24 \mathrm{hrs}$ to the termination of the experiment in accordance with AchionyeNzeh et al. (2004) method. Data obtained were analysed with appropriate statistical methods.

Liver homogenate was prepared as described by Babalola and Areola, (2010).

Assay of Glutathione S-Transferase (GST) and Superoxide Dismutase (SOD) in the Liver Homogenate of C. gariepinus

Glutathione S-transferase activity was determined by following the method of Habig et al. (1974) while the SOD assay was carried out as described by Fridovic and Maccord (1969).

\section{Haematological Analysis}

Fish were removed from each tank and cleaned with a wet towel. Blood was then collected by making an incision on the caudal peduncle of the fish; the flow of blood was directed into well labelled bottles of potassium ethylene-diaminetetraacetic acid (K+EDTA). The blood samples were analysed at the Department of Haematology, College of Health Science, Obafemi Awolowo University, Ile-Ife.

\section{Tissue Digestion for AAS Analysis}

One $(1 \mathrm{~g})$ each of the separate tissues (liver, gills and muscle) was placed in a test tube; $5 \mathrm{ml}$ of concentrated nitric acid was carefully added to each tube, covered with cotton wool and left on the bench overnight. The following day, the wool was removed and the reacting mixture in tubes were boiled in water bath for $1 \mathrm{hr}$. The tubes were removed from water bath and allowed to cool and then diluted to $25 \mathrm{ml}$ with deionised water. The solution obtained was used for manganese analysis. The concentrations of manganese were determined using PG 990 Atomic Absorption Spectrophotometer.

\section{Histopathology Study}

The histopathology study was done in the Department of Anatomy and Cell Biology, Obafemi Awolowo University, Ile-Ife.

\section{Statistical Analysis}

The statistical package used for data analysis was IBM SPSS Inc version 20.0 and Microsoft Excel 2013 version. Statistical data obtained from this study were presented as mean \pm SEM (Standard Error of Mean) and the significant mean differences were separated at 0.05 probability levels.

\section{RESULTS}

Physico-chemical Quality of Culture Media

The mean values of physico-chemical parameters of the culture media are summarized in tab1e 1 . The highest weekly temperature value recorded was $26.02 \pm 1.11^{\circ} \mathrm{C}$ while the lowest weekly water temperature recorded was $25.82 \pm 0.89^{\circ} \mathrm{C}$. The variation in water temperature showed that the groups containing manganese were not significantly different $(p<0.05)$ from the control. Changes in $\mathrm{pH}$ of the culture water showed that the group with the highest concentration of manganese had the highest mean $\mathrm{pH}$ of $7.54 \pm$ 0.62 while the control had the lowest mean $\mathrm{pH}$ of $6.69 \pm 0.31$. It was observed that as the concentrations of manganese increases, the water $\mathrm{pH}$ also increases. The changes in $\mathrm{pH}$ showed that the water $\mathrm{pH}$ of the groups treated with manganese were not significantly different $(\mathrm{p}<$ 0.05) from the $\mathrm{pH}$ of the control. 
Table1: The mean values of Physico-chemical Parameters of the Culture media

\begin{tabular}{llllll}
\hline \multicolumn{7}{c}{ Concentrations of Manganese Chloride (mg/L) } \\
Parameters & Control & Group A & Group B & Group C & Group D \\
\hline Temperature $\left({ }^{\circ} \mathrm{C}\right)$ & $26.05 \pm 1.21$ & $25.82 \pm 0.89$ & $25.85 \pm 1.25$ & $26.02 \pm 1.11$ & $26.01 \pm 1.26$ \\
pH & $6.69 \pm 0.31$ & $7.0 \pm 0.21$ & $7.13 \pm 0.27$ & $7.36 \pm 0.34$ & $7.54 \pm 0.62$ \\
DO $(\mathrm{mg} / \mathrm{L})$ & $6.93 \pm 0.22$ & $6.95 \pm 0.53$ & $6.72 \pm 0.22$ & $6.70 \pm 0.36$ & $6.47 \pm 0.28$ \\
Conductivity & $5.31 \pm 0.11$ & $11.14 \pm 0.25$ & $13.92 \pm 0.59$ & $16.29 \pm 1.55$ & $20.67 \pm 1.06$ \\
$(\mu \mathrm{s} / \mathrm{cm})$ & & & & & \\
\hline
\end{tabular}

Values are expressed as Mean \pm SEM, $\mathrm{n}=5$

Concentrations of manganese chloride: $A=68.5 \mathrm{mg} / \mathrm{L}, \quad B=137, C=205.5 \mathrm{mg} / \mathrm{L}, \mathrm{D}=274 \mathrm{mg} / \mathrm{L}, \mathrm{DO}-$ Dissolved oxygen

The mean concentration of dissolved oxygen (DO) of the culture water obtained for all the groups ranges from $6.95 \pm 0.53 \mathrm{mg} / \mathrm{L}$ to $6.47 \pm$ $0.28 \mathrm{mg} / \mathrm{L}$. The results obtained showed that there was no significant difference $(\mathrm{P}>0.05)$ in dissolved oxygen of water of fish exposed to manganese however a significant decrease $(\mathrm{P}<0.05)$ was observed between dissolved oxygen of water in the control and the group with highest manganese concentration.

The weekly conductivity of the culture water ranged from 4.59 to $23.52 \mu \mathrm{s} / \mathrm{cm}$. The group with the highest manganese concentration had the higest conductivity value. Generally, it was observed that as the manganese concentration increases, the mean conductivity values also increases.
Behavioural Changes Observed in $C$. gariepinus During Acute Toxicity Study

Behavioural changes observed during acute toxicity test include loss of reflex, moulting, discolouration, air gulping, erratic swimming, barbell deformation and excessive mucus secretion in the test organisms. These parameters were monitored and recorded for the varying concentration of manganese. Loss of reflex was observed only in group $\mathrm{D}$ with highest concentration of $\mathrm{Mn}$ within $24 \mathrm{hr}$ of exposure. However, at $96 \mathrm{hr}$ of acute toxicity test, group B, C and $\mathrm{D}$ showed loss of reflex. The behavioural responses observed increased with the metal concentration as shown in table 2 . The table also confirmed other behavioural changes noticed in the experimental organisms exposed to varying concentration of manganese.

Table 2: Behavioural Changes Observed in C. gariepinus During Acute Toxicity Study

\begin{tabular}{|c|c|c|c|c|c|c|c|c|c|c|c|c|c|c|c|c|c|c|c|c|}
\hline $\begin{array}{l}\text { Exposure Time } \\
\text { (hr) }\end{array}$ & 24 & & & & & 48 & & & & & 72 & & & & & 96 & & & & \\
\hline $\mathrm{MnCl}_{2}(\mathrm{~g} / \mathrm{l})$ & 0 & 2 & 3 & 4 & 5 & 0 & 2 & 3 & 4 & 5 & 0 & 2 & 3 & 4 & 5 & 0 & 2 & 3 & 4 & 5 \\
\hline \multicolumn{21}{|l|}{ Behaviour } \\
\hline Loss of reflex & - & - & - & - & + & - & - & - & + & + & - & - & - & + & + & - & - & + & + & + \\
\hline Moulting & - & - & - & + & + & - & - & + & + & + & - & - & + & + & + & - & + & + & + & + \\
\hline Discolouration & - & - & - & - & - & - & - & - & - & + & - & - & - & + & + & - & - & + & + & + \\
\hline Air Gulping & - & - & - & - & + & - & - & - & + & + & - & - & + & + & + & - & + & + & + & + \\
\hline $\begin{array}{l}\text { Erratic } \\
\text { Swimming }\end{array}$ & - & - & - & + & + & - & - & + & + & + & - & - & + & + & + & - & + & + & + & + \\
\hline $\begin{array}{l}\text { Barbel } \\
\text { Deformation }\end{array}$ & - & - & - & - & - & - & - & - & + & + & - & - & + & + & + & - & - & + & + & + \\
\hline $\begin{array}{l}\text { Excessive } \\
\text { Mucous } \\
\text { Secretion }\end{array}$ & - & - & - & - & - & - & - & - & - & - & - & - & - & + & + & - & - & - & + & + \\
\hline
\end{tabular}

Key: $+=$ Present, $\quad-=$ Absent 


\section{Mortality during Acute Toxicity Study}

During the $96 \mathrm{hr}$ acute toxicity study, mortality was recorded in all the treatment groups. Fish in Group A, B, and C had no mortality at $24 \mathrm{hr}$ of exposure while group $\mathrm{D}$ with the highest concentration of manganese had $20 \%$ mortality. At 48 hr of exposure, mortality rate rose to $60 \%$ in group D, 20\% in group C and no mortality was observed in group B and A. Group D had mortality rate of $80 \%$ at $72 \mathrm{hr}$ of acute toxicity test while mortality rose to $40 \%$ in group C, $20 \%$ for group B and no record of mortality in Group A. Nevertheless, mortality rose to $100 \%$ in group D, $80 \%$ in group C, $60 \%$ in group B and $20 \%$ in group A as shown in table 3 .

Table 3: Mortality of Fish during Acute Toxicity Study.

\begin{tabular}{llllll}
\hline Time of Exposure(hrs) & Control & A & B & C & D \\
\hline 24 & - & - & - & - & 1 \\
48 & - & - & - & 1 & 2 \\
72 & - & - & 1 & 1 & 1 \\
96 & - & 1 & 2 & 2 & 1 \\
Total Mortality & $0 / 5$ & $1 / 5$ & $3 / 5$ & $4 / 5$ & $5 / 5$ \\
Total Mortality (\%) & 0 & 20 & 60 & 80 & 100 \\
\hline
\end{tabular}

Manganese chloride concentration: Group A (2 g/L), Group B (3 g/L), Group C (4 g/L), Group D (5 g/L).

\section{Determination of $\mathbf{L C}_{50}$}

The lethal concentration $\left(\mathrm{LC}_{50}\right)$ was calculated from the graph of manganese concentrations against mortality. The $\mathrm{LC}_{50}$ value obtained from the graph was $2.74 \mathrm{~g} / \mathrm{L}$.

\section{Sub-chronic Toxicity Study}

The fish mortality was expressed as the number of dead fish per bowl in the control and the groups with manganese throughout the exposure period. There was no mortality during the 28 days subchronic test in treatment bowls and the control, survival rate was $100 \%$.

\section{Growth Performance Indices}

The growth performance of C. gariepinus cultured in varying concentration of, manganese under renewal biostatic system for 28 days is presented in table 4. There was no significant difference $(\mathrm{P}>$ 0.05) in the initial weight (Wi) of fish exposed to manganese and the control. The mean weight gained (MWG) decreases from group A with
MWG of $34.00 \pm 0.53 \mathrm{~g}$ to group D with MWG of $22.10 \pm 0.72 \mathrm{~g}$. As the manganese concentration increases, the MWG decreases. There was a significant difference $(\mathrm{P}<0.05)$ in mean weight gained between the fish in the control group and the fish cultured in varying concentration of manganese. Specific growth rate (SRG) values decrease as the concentrations of manganese increases, fish in control group had the highest SGR while the fish with highest concentration of manganese had the lowest SGR. Feed conversion ratio (FCR) was found to increase as the concentration of manganese increases; as a result of this, the control group had the lowest FCR while the group with highest manganese concentration had the highest FCR (table 4). Comparison of the FCR values between the control group and groups with manganese showed that the difference between them were statistically significant $(\mathrm{P}<0.05)$. FCR is therefore inversely proportional to SGR, as FCR increases; SGR deceases (figure 1). 
Table 4: The Growth and Performance of C.gariepinusin Different Concentration of Manganese

\begin{tabular}{llllll}
\hline Index & Control & $\mathrm{A}$ & $\mathrm{B}$ & $\mathrm{C}$ & $\mathrm{D}$ \\
\hline $\mathrm{W}_{\mathrm{i}}(\mathrm{g})$ & $50.20^{\mathrm{a}} \pm 0.50$ & $49.80^{\mathrm{a}} \pm 0.45$ & $49.50^{\mathrm{a}} \pm 0.75$ & $52.50^{\mathrm{a}} \pm 0.55$ & $51.50^{\mathrm{a}} \pm 0.85$ \\
$\mathrm{~W}_{\mathrm{f}}(\mathrm{g})$ & $86.60^{\mathrm{a}} \pm 0.48$ & $83.80^{\mathrm{ab}} \pm 0.69$ & $80.80^{\mathrm{b}} \pm 0.46$ & $80.60^{\mathrm{b}} \pm 0.59$ & $73.60^{\mathrm{bc}} \pm 0.74$ \\
MWG $(\mathrm{g})$ & $36.40^{\mathrm{a}} \pm 0.58$ & $34.00^{\mathrm{b}} \pm 0.53$ & $31.40^{\mathrm{ab}} \pm 0.39$ & $28.10^{\mathrm{b}} \pm 0.48$ & $22.10^{\mathrm{c}} \pm 0.72$ \\
SGR & $2.51^{\mathrm{a}} \pm 0.23$ & $1.86^{\mathrm{ab}} \pm 0.28$ & $1.71^{\mathrm{ab}} \pm 0.43$ & $1.68^{\mathrm{ab}} \pm 0.33$ & $1.40^{\mathrm{c}} \pm 0.27$ \\
FCR & $1.93^{\mathrm{b}} \pm 0.37$ & $2.05^{\mathrm{b}} \pm 0.56$ & $2.21^{\mathrm{b}} \pm 0.46$ & $2.61^{\mathrm{a}} \pm 0.43$ & $3.26^{\mathrm{a}} \pm 0.09$ \\
SR $(\%)$ & 100 & 100 & 100 & 100 & 100 \\
\hline
\end{tabular}

Values are expressed as Mean \pm SEM, $\mathrm{n}=5$

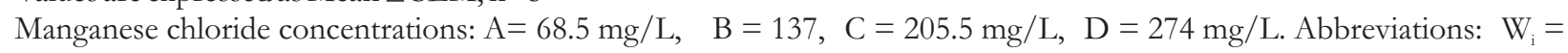
Initial body weight, $\mathrm{W}_{\mathrm{f}}=$ Final body weight, $\mathrm{MWG}=$ Mean Weight gained, FCR $=$ Feed Conversion Ratio, $\mathrm{SGR}=\mathrm{Specific}$ Growth Rate and SR = Survival Rate.

Values with subscripts are statistically different at $\mathrm{p}<0.05$ when compared with the control group.

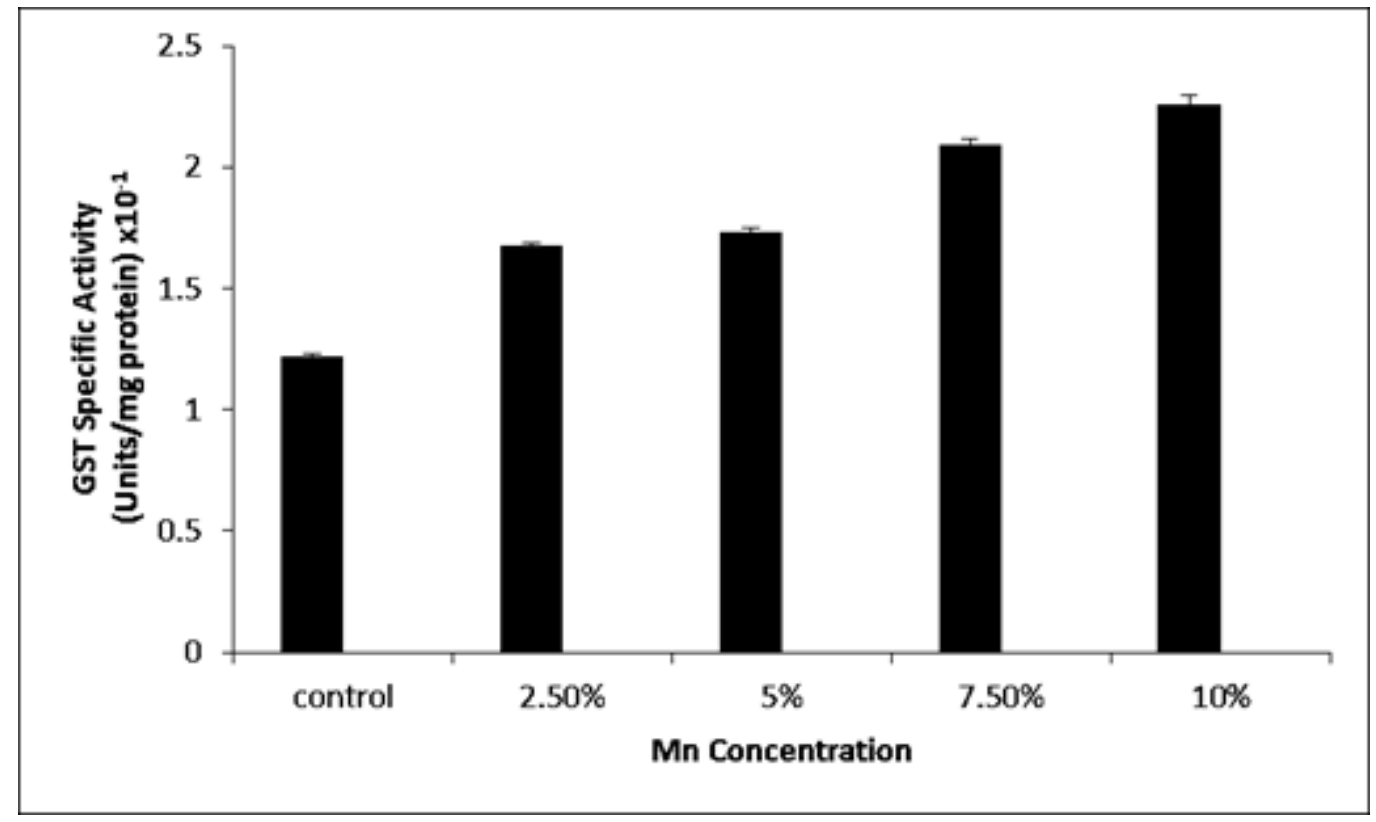

Figure 1: Activity of GST in liver of C. gariepinus on exposure to various concentrations of manganese for a period of 28 days. The results are represented as Mean \pm SEM, $\mathrm{n}=5$.

$\left[\mathrm{MnCl}_{2}\right] 2.5 \%=68.5 \mathrm{mg} / \mathrm{L}, 5 \%=137 \mathrm{mg} / \mathrm{L}, 7.5 \%=205.5 \mathrm{mg} / \mathrm{L}$ and $10 \%=274 \mathrm{mg} / \mathrm{L}$

\section{Effects Manganese Exposure on}

Haematological Parameters of C. gariepinus

The results of haematological parameters of $C$. gariepinus subjected to sub-chronic concentrations of manganese and the control are shown in table 5. The results showed that white blood cell count in the experimental fish increase as manganese concentration increases. The white blood counts were not significantly different from the control at $(\mathrm{P}<0.05)$. However, at a manganese concentration greater than $137 \mathrm{mg} / \mathrm{L}$, it showed a significant variation at $(\mathrm{P}<0.05)$ from the control.. Decrease in the red blood cell (RBC) values were also observed as the concentration of manganese increases. Although, the difference between the control and fish cultured in manganese were not significantly different in $\mathrm{RBC}$ values except at 274 $\mathrm{mg} / \mathrm{dL}(\mathrm{P}<0.05)$.

Furthermore, the fish exposed to $68.5 \mathrm{mg} / \mathrm{L}$ had haemoglobin (HGB) concentration that was not significantly different $(\mathrm{P}>0.05)$ from the control. However, the fish in other manganese concentrations showed a decrease in the haemoglobin concentration and the decreases were significantly different $(\mathrm{P}<0.05)$ from the control group. The values obtained for mean concentration of haemoglobin $(\mathrm{MCH})$ and platelet (PLT) followed the same trend in all the groups as shown in table 5 . 
Table 5: Effect of Manganese on Haematological Parameters of C. gariepinus after 28 Days Exposure

\begin{tabular}{llllll}
\hline Parameters & \multicolumn{5}{c}{ Manganese Treatment (Dose) } \\
\cline { 2 - 6 } & Control & $\mathrm{A}$ & $\mathrm{B}$ & $\mathrm{C}$ & $\mathrm{D}$ \\
\cline { 2 - 6 } $\mathrm{WBC}\left(10^{3} / \mu \mathrm{L}\right)$ & $50.11^{\mathrm{a}} \pm 0.14$ & $52.32^{\mathrm{a}} \pm 0.08$ & $51.59^{\mathrm{ab}} \pm 0.23$ & $58.91^{\mathrm{b}} \pm 0.17$ & $62.83^{\mathrm{b}} \pm 0.19$ \\
$\mathrm{RBC}\left(10^{6} / \mu \mathrm{L}\right)$ & $2.73^{\mathrm{a}} \pm 0.22$ & $2.48^{\mathrm{ab}} \pm 0.32$ & $2.43^{\mathrm{ab}} \pm 0.29$ & $2.41^{\mathrm{ab}} \pm 0.11$ & $2.21^{\mathrm{b}} \pm 0.16$ \\
$\mathrm{HGB}(\mathrm{g} / \mathrm{dL})$ & $12.33^{\mathrm{a}} \pm 0.45$ & $12.27^{\mathrm{a}} \pm 0.32$ & $11.42^{\mathrm{ab}} \pm 0.24$ & $10.76^{\mathrm{b}} \pm 0.29$ & $9.29^{\mathrm{b}} \pm 0.42$ \\
$\mathrm{LYM}\left(10^{3} / \mu \mathrm{L}\right)$ & $94.40^{\mathrm{a}} \pm 0.23$ & $94.90^{\mathrm{a}} \pm 0.15$ & $96.5^{\mathrm{b}} \pm 0.09$ & $96.4^{\mathrm{b}} \pm 0.37$ & $94.2^{\mathrm{a}} \pm 0.38$ \\
$\mathrm{MCH}(\mathrm{pg})$ & $46.93^{\mathrm{a}} \pm 0.09$ & $45.10^{\mathrm{a}^{\mathrm{a}} \pm 0.43}$ & $46.90^{\mathrm{a}} \pm 0.22$ & $44.30^{\mathrm{ab}} \pm 0.38$ & $41.60^{\mathrm{b}} \pm 0.14$ \\
$\mathrm{MCHC}(\mathrm{pg} / \mathrm{dL})$ & $38.66^{\mathrm{a}} \pm 0.25$ & $34.41^{\mathrm{ab}} \pm 0.14$ & $32.18^{\mathrm{ab}} \pm 0.19$ & $31.64^{\mathrm{a}} \pm 0.21$ & $31.74^{\mathrm{a}} \pm 0.12$ \\
$\mathrm{PLT}\left(10^{3} / \mu \mathrm{L}\right)$ & $57.45^{\mathrm{a}} \pm 0.28$ & $42.39^{\mathrm{a}} \pm 0.22$ & $46.43^{\mathrm{ab}} \pm 0.29$ & $48.35^{\mathrm{ab}} \pm 0.31$ & $41.57^{\mathrm{a}} \pm 0.21$ \\
\hline
\end{tabular}

Values with different subscripts are significantly different at $\mathrm{p}<0.05$. Values are expressed as Mean $\pm \mathrm{SEM}, \mathrm{n}=5$, Manganese chloride concentration: $A=68.5 \mathrm{mg} / \mathrm{L}, \mathrm{B}=137 \mathrm{mg} / \mathrm{L}, \mathrm{C}=205.5 \mathrm{mg} / \mathrm{L}$ and D=274mg $/ \mathrm{L}$

Abbreviations: $\quad \mathrm{RBC}=$ Red Blood Cell Count, $\mathrm{WBC}=$ White Blood Cell Count, PLT $=$ Platelet Count, HBG = Haemoglobin, $\mathrm{MCH}=$ Mean Corpuscular Haemoglobin, $\mathrm{MCHC}=$ Mean Corpuscular Haemoglobin Concentration.

\section{Glutathione transferase Activity (GST)}

The values of GST actvity revealed that there was a significant variation $(\mathrm{p}<0.05)$ in GST specific activity in liver of the juvenile $C$. garipinus between the control and the treatment groups. The values revealed that the specific activity of GST in the liver of fish exposed to various manganese concentrations were significantly higher $(\mathrm{p}<0.05)$ than GST activity in the liver of the fish in the control as shown in figure 1.

\section{Superoxide Dismutase (SOD) Activity}

The SOD activity increased as the concentration of manganese increases in the C. gariepienus liver. The difference in SOD activity at lower concentrations of manganese were not significant but at higher concentrations (205.5 and 274 $\mathrm{mg} / \mathrm{L})$, there were significant differences at $\mathrm{p}<0.05$ when compared with the control (Figure 2).

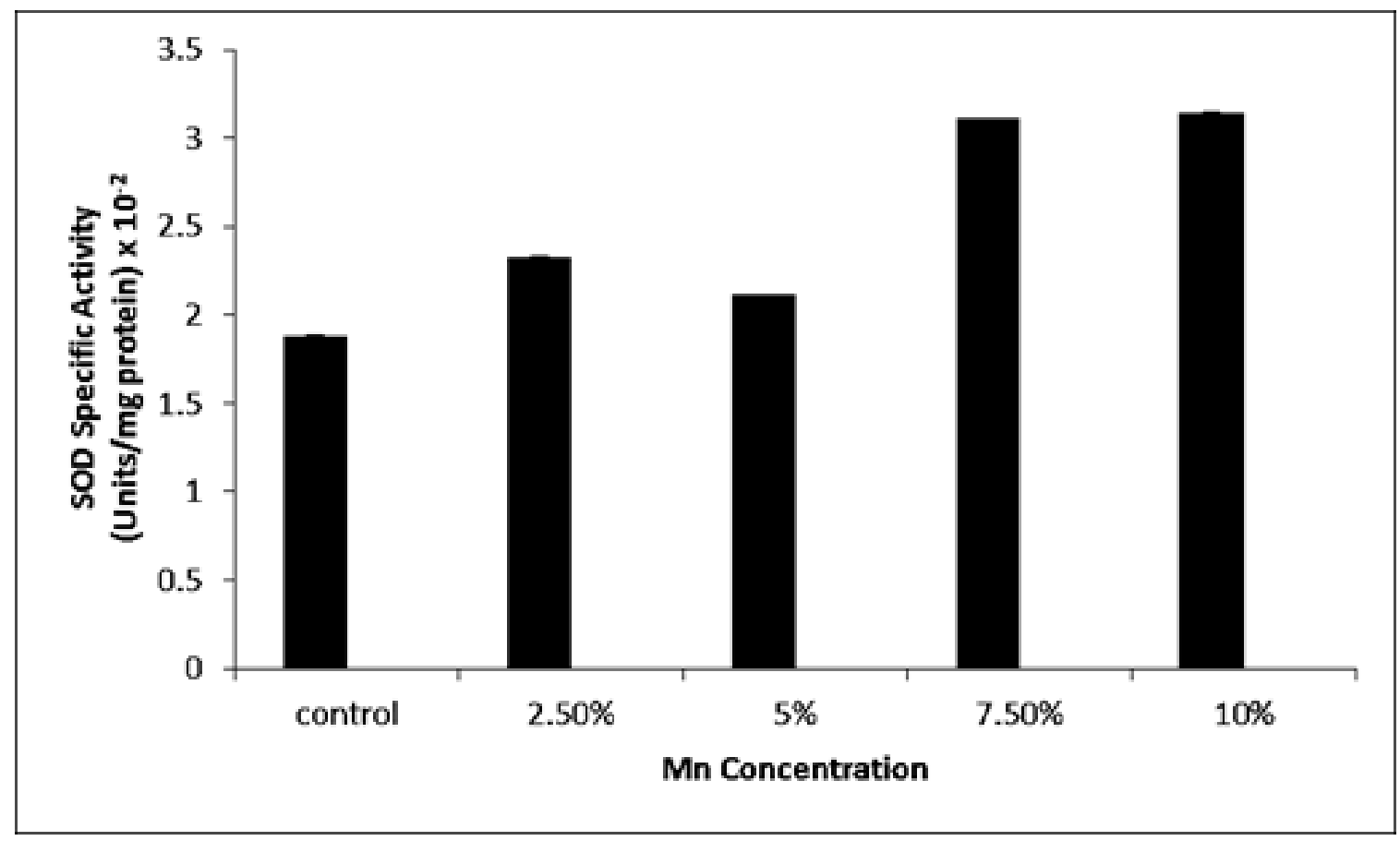

Figure 2: Activity of SOD (U/mg protein) in Liver C. gariepinus Exposed to Various Concentrations of Manganese for a Period of 28 days.

The results are represented as Mean $\pm \mathrm{SD}, \mathrm{n}=5$.

$\left[\mathrm{MnCl}_{2}\right] 2.5 \%=68.5 \mathrm{mg} / \mathrm{L}, 5 \%=137 \mathrm{mg} / \mathrm{L}, 7.5 \%=205.5 \mathrm{mg} / \mathrm{L}$ and $10 \%=274 \mathrm{mg} / \mathrm{L}$ 


\section{Analysis of Manganese Concentrations in} Tissues of C. gariepinus

The graphical representation of concentrations $(\mu \mathrm{g} / \mathrm{g})$ of manganese in organs of C. gariepienus exposed to sub-chronic concentrations of manganese for 28 days is shown in figure 3 . The liver of fish exposed to $274 \mathrm{mg} / \mathrm{L}$ manganese had the highest bioaccumulation of $2.34 \pm 0.039 \mu \mathrm{g} / \mathrm{g}$ of manganese followed by the gill $(1.65 \pm 0.108$ $\mu \mathrm{g} / \mathrm{g})$ while the muscle had the lowest concentration of $1.39 \pm 0.163 \mu \mathrm{g} / \mathrm{g}$. In groups with lower concentration of manganese (68.5 $\mathrm{mg} / \mathrm{L}, 137 \mathrm{mg} / \mathrm{L}$ ), the rate of manganese bioaccumulation was found to be in the order of gill $>$ muscle $>$ liver while fish exposed to higher concentration of manganese $(205.5 \mathrm{mg} / \mathrm{L}, 274$ $\mathrm{mg} / \mathrm{L})$ was in the order of liver $>$ gill $>$ muscle. The difference in the bioaccumulation in the various organs/tissues however did not differ significantly at $(\mathrm{P}<0.05)$ in fish exposed to lower concentration of $\mathrm{Mn}$ but there was a significant difference in the rate of bioaccumulation of manganese in organs of fish exposed to 205.5 $\mathrm{mg} / \mathrm{L}$ and $274 \mathrm{mg} / \mathrm{L}$.

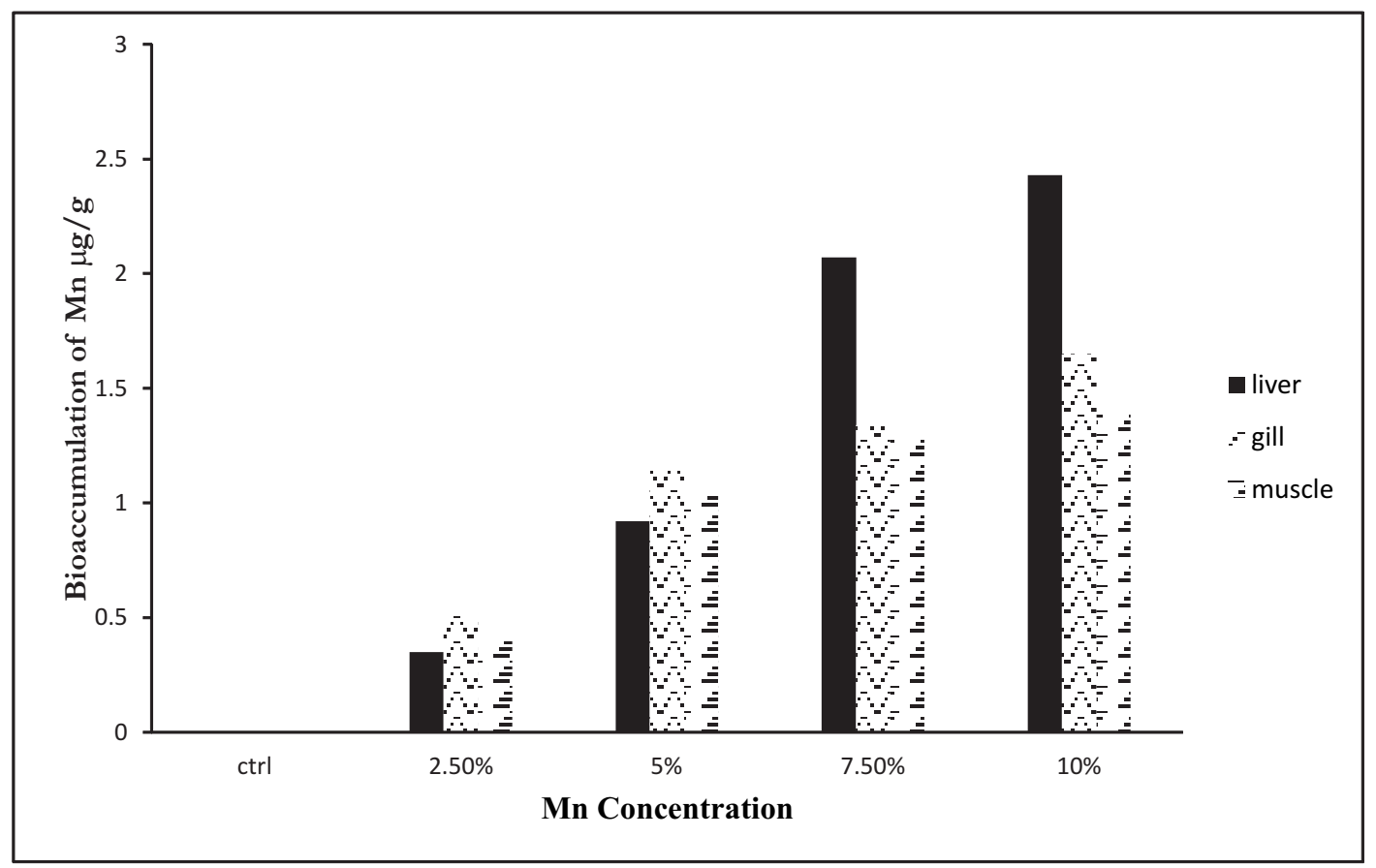

Figure 3: Bioaccumulation of Manganese in Organs of C. gariepinus

\section{Histopathology}

The histopathology of different $C$. gariepinus tissues revealed that there were several histopathological changes in different organs/tissues (liver, gills, and muscle) of the fish subjected to varying concentrations of manganese as shown in plates 1 and 2

\section{Histopathological Changes in the Liver}

In the present investigation, the photomicrograph of liver of the control fish exhibited a normal architecture with hepatocytes presenting a homogenous cytoplasm and a spherical nucleus (N) (Plate 1). The liver of fish exposed to 68.5 $\mathrm{mg} / \mathrm{L}$ of manganese exhibited focal area of necrosis (NC), while the liver of fish exposed to $137 \mathrm{mg} / \mathrm{L}$ and $205.5 \mathrm{mg} / \mathrm{L}$ of manganese showed liver anomalies such as degenerative nuclei (DN), cytoplasmic vacuolation (CV) and necrosis (NC) (Plates 1b and 1c). In plate 1d, the photomicrograph of liver of the fish exposed to $274 \mathrm{mg} / \mathrm{L}$ of manganese was seen to have severe abnormalities such as irregular shaped hepatocytes and nucleus in a lateral position. Also, hepatocytes were located among blood capillaries called sinusoids (SS) forming cord-like structures which indicate vascular dilation (D), congestion and dilation of sinusoids (CS and DS).

\section{Histopathological Changes in the Gills}

The gill is made up of filaments of primary lamellae arranged in double rows. Secondary lamellae arise from these filaments. The secondary 
lamellae are lined by a squamous epithelium. Plate 2 shows the control gill tissues which consisted of primary lamellae (PL) and secondary lamellae (SL). The secondary lamellae composed of a single layer of epithelial cells. There were no conspicuous changes in the gill tissues of the control fish. However, plates $2 \mathrm{a}$ and $\mathrm{b}$ shows the gill tissues of C. gariepinus exposed to $68.5 \mathrm{mg} / \mathrm{L}$ and $137 \mathrm{mg} / \mathrm{L}$ of manganese. Shortening of secondary lamellar was observed in plate $2 \mathrm{a}$, while plate $2 \mathrm{~b}$ showed fusion of secondary lamellae, degeneration of the epithelia and mild epithelial vacuolation of the secondary lamellae .Plate $2 \mathrm{c}$ and $\mathrm{d}$ represents the photomicrograph of gill tissues of fish exposed to $205.5 \mathrm{mg} / \mathrm{L}$ and 274 $\mathrm{mg} / \mathrm{L}$ of manganese respectively, plate $2 \mathrm{c}$ reveals degenerating epithelia and hyperplasia of the secondary lamellae while plate $2 \mathrm{~d}$ shows aneurysm around the primary lamellae and epithelia of the secondary lamellae

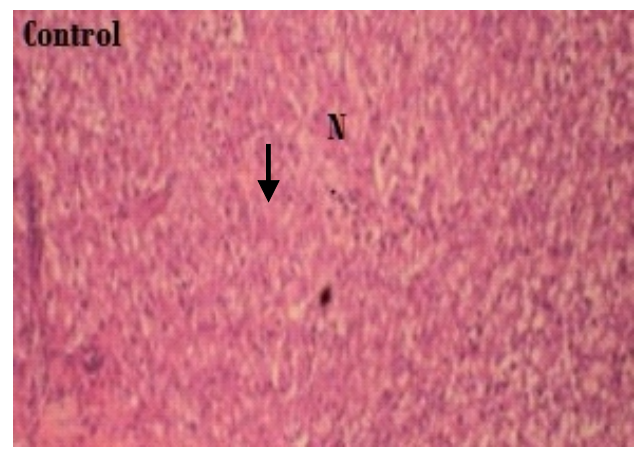

Plate 1: Control

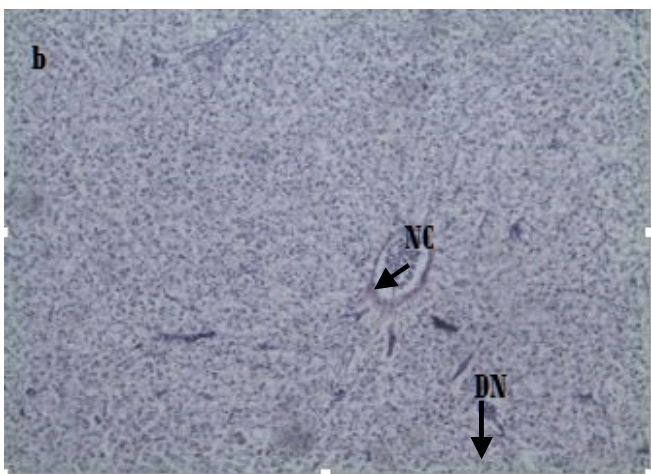

Plate $1 \mathrm{~b}$

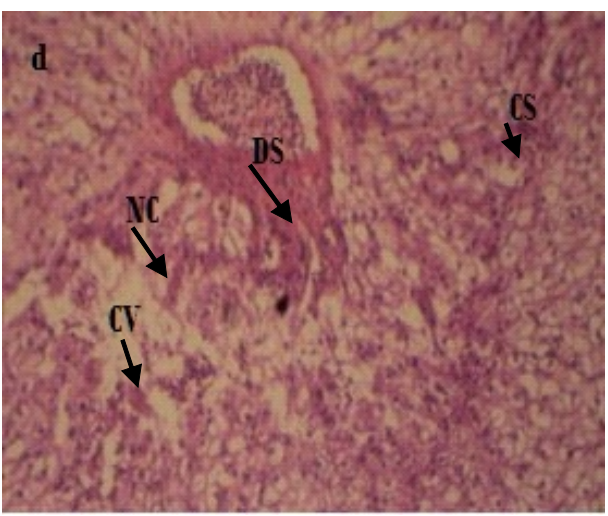

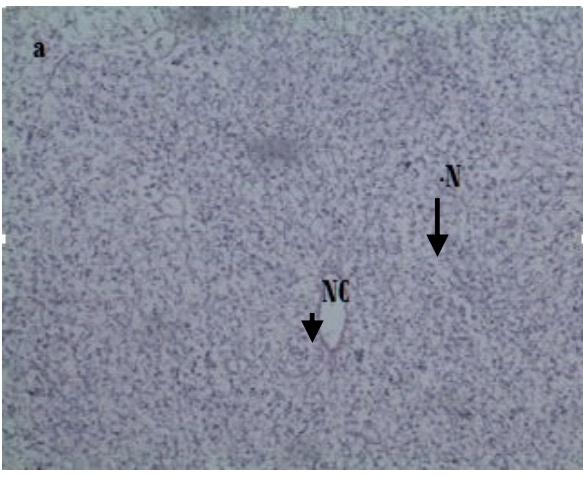

Plate $1 \mathrm{a}$

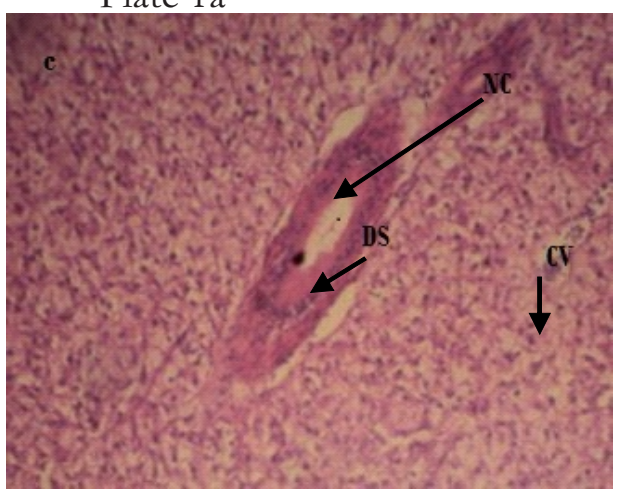

Plate 1c

Plate 1.d

Photomicrograph of Liver Section of Rat (Plates a, b, c and d) Exposed to 68.5, 137, 205 and $274 \mathrm{mg} / \mathrm{L}$ of $\mathrm{MnCl}_{2}$ respectively, together with the Control (mag. x 100).

Abbreviations: Spherical Nucleus (N), Area of Necrosis (NC), Degenerative Nuclei (DN), Cytoplasmic Vacuolation (CV), Vascular Dilation (D) and Congestion and Dilation of sinusoids (CS and DS). 


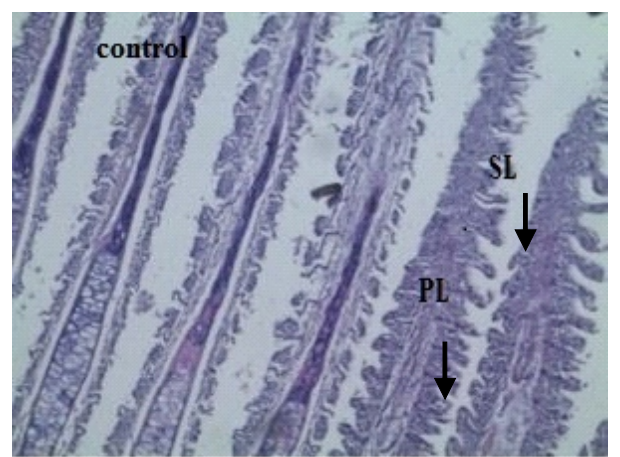

Plate 2: Control

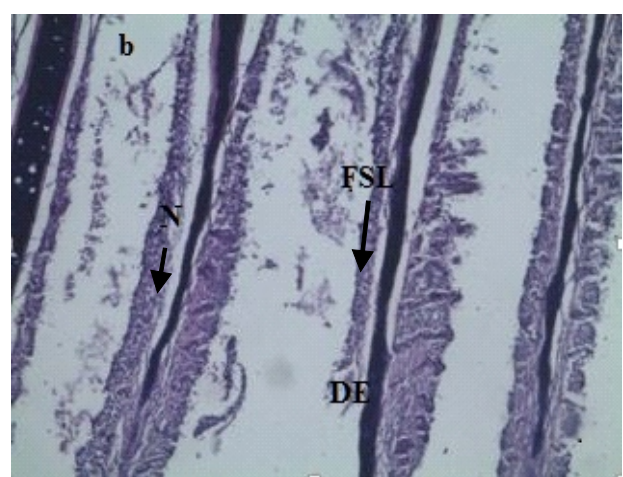

Plate: $2 \mathrm{~b}$

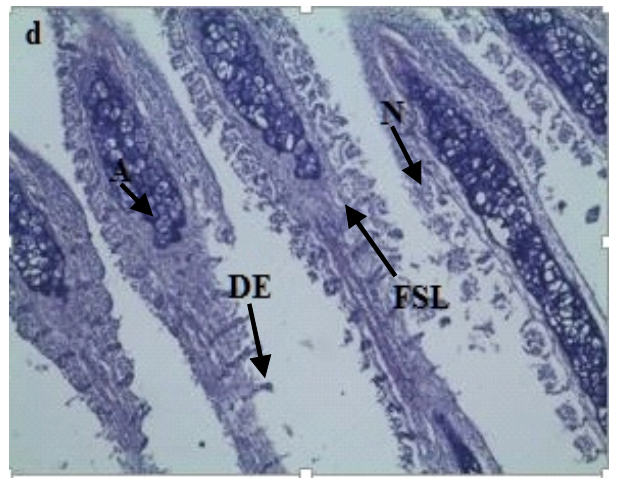

Plate: $2 \mathrm{~d}$

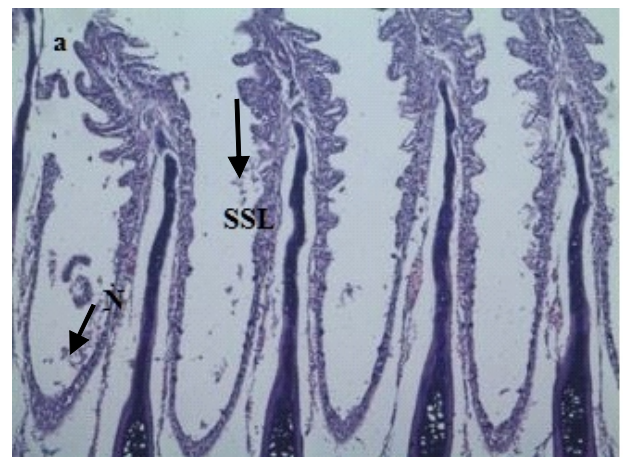

Plate: $2 \mathrm{a}$

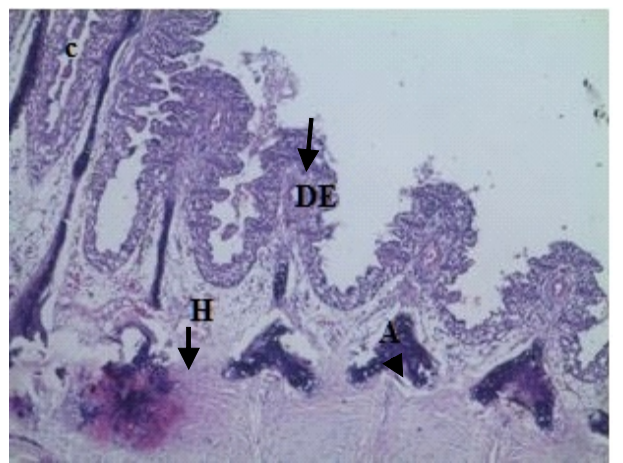

Plate: 2c

Photomicrograph of Gill Section of rat (Plates a, b, c and d) Exposed to 68.5, 137, 205 and $274 \mathrm{mg} / \mathrm{L}$ of $\mathrm{MnCl}_{2}$ respectively together with the Control (mag. x100).

Abbreviations: Primary Lamellae (PL), Secondary Lamellae (SL), Fusion of Secondary Lamellae (FSL), Shortening of Secondary Lamellae (SSL), Hyperplasia (H), Degenerative Epithelium (DE), Focal Area of Necrosis (N), Fusion of Secondary Lamellae (FSL).

\section{DISCUSSION}

Water quality plays a major role in the growth and gross fish production. Owing to its significance, fish farmers always keep these parameters under consideration when siting their fish ponds. The results of physicochemical analysis of the culture water containing varying concentrations of manganese showed that $\mathrm{pH}$ increases with increase in manganese concentrations.
Nevertheless, the $\mathrm{pH}$ of the water decreases with time of exposure (day 1 to 3 ) in all the groups exposed to manganese. Temperature has a profound effect on biological processes; the metabolic activity of aquatic organisms also increases with increase in temperature (Howerton, 2001). The normal range of temperature in the tropics to which fish is adapted is $22-35{ }^{\circ} \mathrm{C}$ (WHO, 2008). The mean temperature recorded during this 
study was within the recommended limit for fresh water fishes. Also, there was no significant difference $(p<0.05)$ between the control and the groups exposed to manganese.

Studies have shown that suitable water quality for any fish culture in the tropical region must have dissolved oxygen concentration of at least $3 \mathrm{mg} / \mathrm{L}$ (Robert, 2007). The mean dissolved oxygen contents recorded in this study was $(6.47-6.95$ $\mathrm{mg} / \mathrm{L})$ greater than $5 \mathrm{mg} / \mathrm{L}$ in all the treated groups. In this study, the dissolved oxygen in water of the manganese groups were significantly different $(p<0.05)$ from the control group. This result however contradicts the report of Khalid, (2011) who observed a decrease in dissolved oxygen concentration with increase in the level of nickel in culture water. The regular and constant changing of culture water may be partly responsible for the high DO recorded in this study. This observation revealed that DO of culture water can be maintained through regular changing of the culture water.

The $96 \mathrm{hr} \mathrm{LC}_{50}$ value obtained for Clarias gariepinus exposed to varying concentrations of manganese in this study was $2.74 \mathrm{~g} / \mathrm{L}$, this value falls within the range of manganese concentration that have been documented in a number of fish species by different authors. For example, Garg et al. (1989) reported $\mathrm{LC}_{50}$ of $3.35 \mathrm{~g} / \mathrm{L}$ in Indian catfish (Heteropneustes fossilis) and $3.01 \mathrm{~g} / \mathrm{L}$ in Indian freshwater murrel (Channa punctatus), Alteration in behaviour is considered as a sensitive biomarker to evaluate the toxicant exposure and effect (Gerhardt, 2007). The studies on fish behaviours provide a lot of knowledge and information because any behaviour alteration can be related to physiological biomarker in aquatic species. The behavioural changes recorded during the acute exposure of $C$. garipinus to varying concentration of manganese include: loss of reflex, moulting, discolouration, air gulping, erratic swimming, barbell deformation and excessive mucus secretion. However, deep behavioural changes observed in fish exposed to higher concentration of manganese showed that it could induce oxidative stress (Javed, 2012). There are many ways that behaviour and physiology can interact to affect aquatic toxicology. A few studies have shown correlations between behavioural and physiological indicators of toxicity and have therefore succeeded in eliminating the complicating effects faced when comparing different behavioural and physiological studies. Affected fish with behavioural alteration toward toxicant especially pesticides and heavy metals has also been reported (Javed, 2012).

A significant decrease in growth parameters were recorded in fish exposed to manganese concentration when compared with the control. Stress-induced reduction in growth is a wellrecognized toxic effect in fish; such effects on growth are expected when organisms are exposed to chemical pollutants, if the exposure is sufficient to produce a stress response. This is the importance of evaluating growth response and oxidative stress in commercially important fish species (Adeogun et al., 2011). The significant variation $(p<0.05)$ in the values of specific growth rate (SGR) of the fish could be attributed to the toxic effects of manganese. The observed increase in FCR of fish exposed to manganese indicated the inability of the fish to convert feed consumed into body protein. This study has revealed that fish exposed to manganese concentration greater than $137 \mathrm{mg} / \mathrm{L}$ will experience poor growth.

The haematological observation showed that the fish cultured in lower manganese concentration had better blood health status than those of higher concentrations. However all the haematological parameters measured in this study were within the recommended physiological range reported for $C$. gariepinus. The blood parameters- RBC and HGB count decreased with increasing concentration of manganese and this become significantly lower ( $\mathrm{P}$ $<0.05)$ at higher concentration when compared with the control. The variation observed in the haematological parameters of fish in this study could be as a result of the toxic effect of manganese. In addition, Roels et al. (1992) have reported adverse haematological effects following occupational exposure to manganese. Oyawoye and Ogunkunle, (1998) reported an increase in white blood cells and lymphocyte count which is usually associated with microbial infection or the presence of foreign bodies. The haematological results obtained from this study revealed that exposure of catfish (Clarias gariepinus) to manganese concentration greater than 205.5 
$\mathrm{mg} / \mathrm{L}$ would have adverse effect on the fish haematological parameters.

The antioxidant enzymes activities were found to increase as the concentration of manganese increases in all the groups. This observation could be due to the fact that exposure of fish to pollutants could trigger the production of antioxidants to overcome stressful conditions generated by such pollutants. Super oxide dismutase (SOD), provides an important means of cellular defence against free radical damage, therefore this could be responsible for higher activities of SOD observed in the liver of fish in groups exposed to manganese. However, this finding conflicts with a report by Olagoke, (2008) who reported a decrease in activities of SOD in fish exposed to polycyclic aromatic hydrocarbons stating that an inhibition of the enzyme SOD will expectedly result in a reduction in the activity of catalase due to a decrease in $\mathrm{H}_{2} \mathrm{O}_{2}$ generation from SOD activities. The GST activities in the liver of the fish exposed to higher manganese concentrations had higher activities when compared with GST activities of fish in the control and those of lower concentrations (2.5 and 5\%). These results are in accordance with the works of Mannervik and Guthenberg (1981) on white fish tissues.

The analysis of metal concentrations in the liver, gill and muscle, showed a significant $(p<0.05)$ difference in the heavy metal concentrations across the organs/tissues of C. gariepinus. The liver of the fish had the highest mean concentrations followed by the gills, while the muscle had the lowest metal concentration. The concentrations of manganese in tissues are different because the rate of metal bioaccumulation is not the same (Karadede et al., 2004). In this study, the metal levels in fish were found to be lowest in the muscle when compared with liver and gills.

The histopathological examination revealed that, the liver of fish exposed to 5, 7.5 and $10 \%$ concentration of manganese revealed degeneration of the hepatocytes, congestion of central vein, necrosis (NC), degenerative nuclei (DN), cytoplasmic vacuolation (CV), vascular dilation (D) and sinusoid congestion (CD) and dilation of sinusoids (DS) in the hepatic cells when compared with the normal hepatic cell in control fish. These results were in accordance with those reported by Van Dyk (2003).

Gill is the first direct contact with water from external environment and changes in fish gill is the most usually distinguished reactions to environmental toxins. In a study by Olojo et al. (2004), it was reported that necrosis and desquamation of gill epithelium as well as lamellar curling and aneurisms were the direct deleterious effects reported in chronic lead exposed $C$. gariepinus. The gill of fish in the control are normal while the gills of fish exposed to manganese showed structural deformation such as epithelial lifting at secondary lamella, hyperplasia of primary epithelium, fusion of secondary lamella, aneurisms, necrosis and infiltration of inflammatory cells with the disintegrate of epithelial cells of secondary lamellae including mucus secretion. It was also reported that edema of the gill epithelium is one of the main structural changes caused by exposure to heavy metals (Mallatt, 1985).

\section{CONCLUSSION}

This study concluded that manganese concentration greater than $137 \mathrm{mg} / \mathrm{L}$ in the pond water had adverse effects on the growth performance generally, therefore such water is not suitable for C.gariepinus farming.

\section{RECOMMENDATION}

Discharge of industrial waste water containing manganese should be regulated to prevent its accumulation in aquatic organisms. Fish farmers should always check the manganese concentrations of their ponds before transferring fish into them. It is also necessary to carry out periodic checks on the quality of fish caught in polluted ponds to prevent human consumption of fish which had been contaminated with metals.

\section{REFERENCES}

Achionye-Nzeh, C.G., Ogidiolu, O. and Salami, S. 2004. Growth response of Clarias anguillaris fingerlings fed diets formulated with Macrotermes nigerensis. Journal of Pure and Appllied Sciences. 19: 1570-1573.

Adeogun, A. O., Chukwuka, A. V. and Ibor, O.R. 2011.Impact of abattoir and saw-mill 
effluents on water quality of upper Ogun river (Abeokuta). American Journal of Environmental Science, 7(6): 525-530.

Adesina, I.M., Bisi-Johnson, M.,Aladesanmi, O.T., Okoh, A.I. and Ogunfowokan, A.O. 2018. Concentrations and human health risk of heavy metals in rivers in southwest Nigeria. Journal of Health ana Polution, 18(19): 1-14.

ASTM, 2007. Standard guide for conducting acute toxicity tests on test materials with fishes, Macroinvertebrates and Amphibians, 11: 6-11.

Babalola, O. O. and Areola, J. O. 2010. Interactive roles of terpenoid extract from the leaves of neem plant (Azadirachta indica, A. juss) on lead induced toxicity in pregnant rabbits. Journal of Medicinal Plants Research, 4(12): 1102-1107.

Baby J., Raj, J.S., Biby, T.E.,Sankargarnesh, P. And Rajan, S.S.2010. Toxic effects of heavy metals on aquatic environment. International Journal of Biological and chemical Science, 4(4):939-952.

CICAD, 2004. Manganese and its compounds: Environmental aspects. Concise international chemical assessment. http:/ /www.who.int/ipcs/publications/ cicad/cicad63_rev_1.pdf

Farombi, E.O. Adelowo, O.A and Y.R. Ajimoo, Y.R., 2007. Biomaker of oxidative stress and heavy metals as indicators of pollution in African catfish (C. gariepinus) from Ogun river, Nigeria. International Journal of Environmental Research and Public Health, 4 (2): 158-165.

Finney, D. J. 1971. Probit Analysis. 3rd ed. Cambridge University press, Cambridge, England. Pp. 333.

Fridovich, J and MacCord, J.M. (1969). Superoxide Dismutases., an enzyme function for erythrocuprein (hemocuprein) Journal of Biological Chemistry., 24 (22): 6049-6055.

Garg V. K., Garg, S. K. and Tyagi, S. K. 1989. Manganese induced hematological and biological anamolies in Heteropneustes fossilis. Journal of Environmental Biology, 10: 249-35.

Gerhardt, A. 2007. Aquatic behavioural ecotoxicology - Prospects and limitations. Human and Ecological Risk Assessment, 13:
481-491.

Habig, W. H., Pabst, M. J. and Jakoby, W. B. 1974. Glutathione-S-transferase. The fist enzymatic step in mercapturic acid formation. Journal of .Biological Chemistry, 49: 7130-7139.

Howerton, R. 2001. Best management practices for Hawaiian aquaculture. Center for tropical and subtropical aquaculture, University of Hawaii, Sea Grant extension services, pp. 148.

Javed, M. 2012. Growth responses of fish under chronic exposure of waterborne and dietary metals. International Journal of AgriculturalBiology, 14: 281-285.

Kamble, S. M. and Tapale, B. K. 2011. Effects of sublethal concentrations of a household detergent on certain biochemical constituents of catfish, Mystus seenghala. Bioscience and Biotechnology Resources Communication, 4: 198-204.

Karadede, H., Oymak, S.A. and Ünlü, E. 2004. Heavy metals in mullet, liza Abu and cat fish, Silurus triostegus, from the Atatürk Dam Lake (Euphrates), Turkey. Environment, 30:183-188.

Khalid, A. G. 2011. Impact of nickel on haematological parameters and behavioural changes in Cyprinus carpio (common carp). African Journal of Biotechnology, 10(63): 13860-13866.

Mallatt, J. 1985. Fish gill structural changes induced by toxicants and other irritants: A statistical review. Canadian Journal of Aquatic Science, 42: 630-648.

Mannervik B, and Guthenberg C. 1981. Glutathione-S-Transferase (human placenta).Methods in Ensymology, 77: 231235.

Obuotor, E. M. 2004. The mode of action of Ichthyotoxic principles in Raphia hookeri fruit. Ph. D. Thesis, Obafemi Awolowo University, Ile-Ife.pp. 172.

Olagoke, O. 2008. Lipid peroxidation and antioxidant defense enzymes in Clarias gariepinus as useful biomark-ers for monitoring exposure to polycyclic aromatic hydro-carbons. M.Sc Theses, University of Lagos, Lagos, Nigeria. pp70.

Olojo, E. A., Olurin, K. B., Mbaka, G. and OluweMimo, A. D. 2004. Histopathology of the 
gill and liver tissues of the African catfish Clarias gariepinus exposed to lead. African Journal of Biotechnology, 4(1): 117 - 122.

Oyawoye, E. O. and Ogunkunle, M. 1998. Physiological and biochemical effects of raw jack beans on broiler. Proceedings of small conference of Nigeria Society of Animal Production, 23: 141-142.

Perl, D.P. and Olanow, C.W. 2007. The neuropathology of manganese-induced Parkinson. Journal of Neuropathology and Experimental Neurology, 66(8): 675-682.

Reish, D. L. and Oshida, P. S. 1987. Manual of methods in aquatic environmental research. Food and Agriculture Organisation (FAO), Rome, pp. 28.

Robert, C. S. 2007. Water quality consideration for aquaculture. Journal of Animal Ecology, 2:1-
15.

Roels, H. A., Ghyselen, P and Buchet, J. P. 1992. Assessment of the permissible exposure level to manganese in workers exposed to manganese dioxide dust. British Journal of Industrial Medicine, 49: 25-34.

Takeda, A. 2003. Manganese action in brain functions. Brain Research Reviews, 41, 79-87.

Van Dyk, J. C. 2003. Histological changes in the liver of Oreochromis mossambicus (cichlidae) after exposure to cadmium and zinc. M.Sc. Thesis, Rand Afrikaans University, South Africa. pp. 28-62.

W.H.O. (2008). UNICEF handbook on water quality. United Nations Children's Fund (UNICEF), New York. pp 45. 